\title{
Medicinal and Cosmetics Uses of Aloe Vera: A Review
}

\author{
Sandeep Kumar Yadav \\ Lecturer, Department of Botany, Govt. Dungar College, Bikaner (Raj.), India
}

\begin{abstract}
Aloe vera is used in allopathic, ayurvedic and ethano medicine. The plant leaves contains numerous bioactive compounds with antimicrobial, anti-oxidant, anti-helmenthic, antifungal, and cosmetic values for health care. This plant leaf has potential to cure sunburns, burn and many skin diseases. The external use in cosmetic mainly acts as skin toner and gives a youthful glow to skin.
\end{abstract}

Keywords: Aloe vera, Ethano medicine, Therapeutic, Medicinal Uses.

\section{INTRODUCTION}

Aloe genus is a succulent herb of maximum $100 \mathrm{~cm}$ in height which matures in 5- 6 years belonging to family Alliaceae. Aloe vera (L.) Burm. f. syn. Aloe barbadensis Miller, is biologically more active compare to other Aloe species [1-3]. Medicinal plants would be the best source for obtaining a variety of drugs According to WHO, [4]. Centre of the origin of plant is southern and eastern Africa along the upper Nile in the Sudan,. The plant is cultivated in Haiti, India, South Africa, the U.S.A., and Venezuela [5,6] while the finest quality of Aloe is grown in desert of California and Ind. The plant can survive in hot temperatures of $40^{\circ}$.

\section{Taxonomic characters}

The succulent perennial herb has triangular, sessile stem, shallow root system, fleshy serrated leaves. The bright yellow tubular flowers, length $25-35 \mathrm{~cm}$, axillary spike and stamens are frequently projected beyond the perianth tube and fruits contain many seeds [6].

\section{Active Principal Components}

The active components of plant are anthraquinones, chromones. The other active principles of Aloe include hydroxyanthrone, aloe-emodin-anthrone 10-C-glucoside. The pungent yellowish gel containing anthraquinones and glycosides has been reported from the middle part of leaf [7]. The anthraquinones and chromones has anticancer activity, antiinflammatory and evacuating [8].

\section{Cosmetics Uses}

The Aloe gel (Muco-polysaccharides) gives chilling effect and also acts as a moisturizing agent. It also has role in rejuvenation of aging skin. Aloe vera gel gloves improved the skin integrity, decrease appearance of acne wrinkle and decrease erythema [9]. The hardened skin cells become softer by the applied form of amino acids present in gel. Zinc proceeds as an astringent to tighten pores.

\section{Medicinal Uses}

Aloe vera is anthelmintic, aperients, carminative, diuretic, stomachic and Juice is used in skin care medicine, dyspepsia, amenorrhea, burns, colic, hyperadenosis, hepatopathy, constipation and dropsy carbuncles. The gel of this plant, is used for helminthiasis in children and is a purgative and anthelmintic. A variety of glycoprotein present in Aloe vera juice has been reported to have anti-tumor and antiulcer effects and to increase proliferation of normal human dermal cells [10-12]. Gel is useful in ulcerative colitis and pressure ulcers, respectively [13, 14]. Traditionally, Aloe vera gel is used both, external (treatment of wounds, minor burns, and skin irritations) and internally to treat constipation, coughs, ulcers, diabetes, headaches, arthritis, immune-system deficiencies [15].

Aloe vera has been used for medicinal purposes in ancient civilization for a long time: Greece, Egypt, India, Mexico, Japan, and China [16]. The Egyptians practiced the Aloe vera to make papyrus like scrolls as well as for treatment of tuberculosis [17-18]. Nadkerni avowed various preparations of Aloe barbadensis like confection, lotion and juice, useful remedies for curing various diseases [19]. Mixture of glucosides obtained from aloe juice collectively called aloin which is the active constituent of various drugs. It is also applied rejuvenation of aging skin. The juice of Aloe vera leaves is used as stomachic tonic and purgative. Scientific evidence for the cosmetic effectiveness of Aloe is limited $[20,21]$. In spite of this, the cosmetic and alternative medicine industries regularly make claims regarding the 
soothing, moisturizing, and healing properties of Aloe vera, especially via internet advertising [22, 23]. The bioactive compounds are used as astringent, antibacterial, anti anticancer agent also, effective in treating stomach ailments, gastrointestinal problems, skin diseases, con-stipation, radiation injury, diarrhoea and in the treatment of skin diseases [24]. It is used in ayurvedic formulations as appetite-stimulant, purgative, and antihelminthic, for treating cough, colds, piles, and jaundice [25].

\section{CONCLUSION}

The bioactive compounds in its leaves have the power to soothe human life and health in a numerous ways. The plant has importance in life to soothe a range of skin disease such as mild cuts, antidote for insect stings, bruises, poison ivy and eczema along with skin moisturizing and anti ageing, digestive tract health, makes it a help to human kind. Aloe vera as the "wonder plant" is multiple from being an antibacterial, anti-carcinogenic agent and being a cosmetic field. The plant is in need to a bigger research importance for better utilization of this plant for mankind. Aloe vera is undoubtedly, the nature's gift to humanity for cosmetic, burn and medicinal application and it remains for us to introduce it to ourselves

\section{REFERENCES}

1 S. P. Joshi, "Chemical Constituents and Biological Activity of Aloe barbadensis-A Review," Journal of Medici nal and Aromatic Plant Sci, 20, 1997, 768-773.

2 D. P. West and Y. F. Zhu, "Evaluation of Aloe vera Gel Gloves in the Treatment of Dry Skin Associated with Occupational Exposure," American Journal of Infection Control, 31(1), 2003, 40-42.

3 A. Yagi, A. Kabash, K. Mizuno, S. M. Moustafa, T. I. Khalifa and H. Tsuji, "Radical Scavenging Glycoprotein Inhibiting Cyclooxygenase-2 and Thromboxane $A_{2}$ Syn-thase from Aloe vera Gel," Planta Medica, 69(3), 2003, 269-271.

4 P. R. V. Santos, A. C. X. Oliveria and T. C. B. Tomassini, "Controls Microbiological Products Fitoterapices," Re-vista de Farmácia e Bioquímica, 31, 1995, 35-38.

5 “African Pharmacopoeia," Vol. 1, Organization of African Unity, Scientific, Technical \& Research Commission, Lagos, 1985.

6 G. Y. Yeh, D. M. Eisenberg, T. J. Kaptchuk and R. S. Phillips, "Systematic Review of Herbs and Dietary Sup-plements for Glycemic Control in Diabetes," Diabetes Care, Vol. 26(4), 2003, 1277-1294.

7 J. P. Brown, “A Review of the Genetic Effects of Naturally Occurring Flavonoids, Anthraquinones and Related Compounds," Mutation Research, 75(3), 1980, 243-277.

8 S. W. Choi, B. W. Son, Y. S. Son, Y. I. Park, S. K. Lee and M. H. Chung, "The Wound-Healing Effect of a Glycoprotein Fraction Isolated from Aloe vera," British Journal of Dermatology, 145(4), 2001, 535-545.

9 D. P. West and Y. F. Zhu, "Evaluation of Aloe vera Gel Gloves in the Treatment of Dry Skin Associated with Occupational Exposure," American Journal of Infection Control, 31(1), 2003, 40-42.

10 S. W. Choi, B. W. Son, Y. S. Son, Y. I. Park, S. K. Lee, and M. H. Chung, "The Wound Healing Effect of a Glycoprotein Fraction Isolated from Aloe vera," British Journal of Dermatology, 145(4), 2001, 535-545.

11 A. Yagi, T. Egusa, M. Arase, M. Tanabe and H. Tsuji, "Isolation and Characterization of the Glycoprotein Fraction with a Proliferation promoting Activity on Human and Hamster Cells in Vitro from Aloe vera Gel," Planta Medica, 63(1), 1997, 18-21.

12 A. Yagi, A. Kabash, K. Mizuno, S. M. Moustafa, T. I. Khalifa and H. Tsuji, "Radical Scavenging Glycoprotein Inhibiting Cyclooxygenase-2 and Thromboxane A2 Syn-thase from Aloe vera Gel," Planta Medica, 69(3), 2003, 269-271.

13 K. Eshun and Q. He, "Aloe vera: A Valuable Ingredient for the Food, Pharmaceutical and Cosmetic Industries-A Review," Critical Reviews in Food Science and Nutrition, 44(2), 2004, 91-96.

14 L. Langmead, R. M. Feakins and S. Goldthorpe, "Randomized, Doubleblind, Placebo-Controlled Trial of Oral Aloe vera Gel for Active Ulcerative Colitis," Alimentary Pharmacology \& Therapeutics, 19(7), 2004, 739-747.

15 D. R. Thomas, P. S. Goode, K. LaMaster and T. Tennyson, “Acemannan Hydrogel Dressing for Pressure Ulcers: A Randomized, Controlled Trial," Advances in Wound Care, 11, 1998, 273-276.

16 B. K. Vogler and E. Ernst, "Aloe vera: A Systematic Review of Its Clinical Effectiveness,” British Journal of General Practice, 49, 1999, 823828 .

17 J. M. Marshall, “Aloe vera Gel: What Is the Evidence?” The Pharmaceutical Journal, 24 1990, 360-362.

18 O.T. Baker, "The Amazing Ancient to Modern Useful Plant Aloe vera: Amazing Plant of the Magic Valley, R. Prevost, Lemon Grove, 1975,

19 K. M. Nadkerni, "Indian Meteria Medica," 3rd Edition, Bombay Popular Prakashan Private Limited, Mumbai, 1976.

20 E Ernst and A. FughBerman, "Methodological Consi-derations in Testing the Efficacy of Complementary/Al-ternative Treatments (CATs)," The Journal of Alternative and Complementary Medicine, 16, 1998, 8-10.

21 J. Marshall, “Aloe vera Gel: What Is the Evidence?” The Pharmaceutical Journal, 244, 2000, 360-362.

22 G. Kunkel, "Plants for Human Consumption,” Koeltz Scientific Books, 1984.

23 M. D. Boudreau and F. A. Beland, "An Evaluation of the Biological and Toxicological Properties of Aloe barbadensis (Miller), Aloe vera," Journal of Environmental Science and Health, 24, 2006, 103-154.

24 T. Rabe and J. Van Staden, “Antibacterial Activity of South African Plants Used for Medicinal Purposes," Journal of Ethnopharmacology, 56(1) $1997,81-87$.

25 B. Joseph and S. J. Raj, "Pharmacognostic and Phytochemical Properties of Aloe vera Linn-An Overview," International Journal of Pharmaceutical Sciences Review \& Research, 4(2) 2010, 106-110. 